\title{
Potential of Small Culverts as Wildlife Passages on Forest Roads
}

\author{
Hsiang-Ling Chen ${ }^{1, *}$, Erin E. Posthumus ${ }^{2} \mathbb{D}$ and John L. Koprowski ${ }^{3}$ \\ 1 Department of Forestry, National Chung Hsing University, 145, Xingda Rd., Taichung 402, Taiwan \\ 2 National Coordinating Office, USA National Phenology Network, School of Natural Resources and the \\ Environment, University of Arizona, Bio Sciences East, 1311 E. 4th St., Tucson, AZ 85721, USA; \\ Erin@usanpn.org \\ 3 Haub School of Environment and Natural Resources, University of Wyoming, 201 Bim Kendall House, \\ 804 E Fremont St., Laramie, WY 82072, USA; jkoprows@uwyo.edu \\ * Correspondence: hsiangling@dragon.nchu.edu.tw
}

Citation: Chen, H.-L.; Posthumus, E.E.; Koprowski, J.L. Potential of Small Culverts as Wildlife Passages on Forest Roads. Sustainability 2021, 13, 7224. https://doi.org/10.3390/ su13137224

Academic Editor: Aleksander Król

Received: 30 April 2021

Accepted: 23 June 2021

Published: 28 June 2021

Publisher's Note: MDPI stays neutral with regard to jurisdictional claims in published maps and institutional affiliations.

Copyright: (c) 2021 by the authors. Licensee MDPI, Basel, Switzerland. This article is an open access article distributed under the terms and conditions of the Creative Commons Attribution (CC BY) license (https:// creativecommons.org/licenses/by/ $4.0 /)$

\begin{abstract}
Roads and traffic can cause animal mortality. Specifically, roads serve as barriers by impeding animal movement, resulting in demographic and genetic consequences. Drainage structures, such as culverts, can provide linkages between habitat patches. However, the potential of small culverts with diameters of $<60 \mathrm{~cm}$ (e.g., wildlife passages that facilitate movement on forest roads) are relatively unknown. In this study, we used trail cameras to monitor the use of 14 small culverts, by mammals, along forest roads on Mt. Graham, home of the critically endangered Mt. Graham red squirrels (Tamiasciurus hudsonicus grahamensis), in southeastern Arizona, USA. From 2011 to 2013, we only recorded 20 completed road crossings through culverts. More than half of culvert uses were by striped skunks (Mephitis mephitis), followed by the rock squirrel (Spermophilus variegatus) and the bobcat (Lynx rufus). The Mt. Graham red squirrel was the only species that was common along the roads, but never crossed the roads. Culverts with higher usages were characterized by shorter culvert lengths and absence of accumulated soil inside the culverts. Our study shows that small-dimension drainage systems may provide alternative pathways for wildlife crossing roads, especially for slow moving and ground dwelling species. However, the potential of small culverts assisting wildlife crossings can only be maximized when culverts are accessible year-round.
\end{abstract}

Keywords: mammals; underpass; drainage; Arizona; road crossing

\section{Introduction}

Habitat fragmentation and destruction are recognized as major threats to biodiversity [1,2]. Road networks represent one of the most significant artificial features on the planet [3]. Road construction not only causes destruction and loss of habitat, but also facilitates deforestation and landscape fragmentation [4,5]. Moreover, roads and traffic can cause animal mortality, serve as barriers by impeding animal movements, reduce reproductive success and gene flow [6-9], and ultimately threaten population persistence [10-12].

Due to the increase in wildlife-vehicle collisions, transportation and resource management agencies have elevated their concerns about road impacts on wildlife and recognized the need to develop effective mitigation [13]. To minimize barrier effects of roads, while simultaneously reducing road mortality, a variety of wildlife passages, including underpasses, overpasses, canopy bridges, and tunnels, have been designed and installed to facilitate movement of wildlife and restore connectivity [14]. Drainage structures, such as culverts and pipes, are often constructed under roads to allow water to drain from the surrounding areas to prevent flooding of road surfaces. A wide range of vertebrates use drainage structures to cross roads (although the structures are not designed specifically for animals) [15-18]. While usage of large culverts (over $1 \mathrm{~m} \times 1 \mathrm{~m}$ ) on highways are relatively well studied, few studies have documented use of small culverts that typically 
have diameters $<60 \mathrm{~cm}$ on low traffic roads, such as forest roads. Forest roads, it is believed, have reduced impacts on wildlife, because roads are often narrow, unpaved, and lightly traveled. However, ecological effects of forest roads are substantial due to wide distribution and facilitating the introduction of human disturbance to remote areas $[2,17,19]$. In the U.S., the National Forest Road System has expanded to $600,000 \mathrm{~km}$ and traffic intensity has grown 10 times since the 1950s, reaching 1.7 million vehicles/day in 1998 [19]. Several studies have demonstrated that even roads $<10 \mathrm{~m}$ wide with low traffic intensity are barriers for many species $[2,20,21]$. The bias of road type and size of crossing structures in previous studies has limited our understanding of road impacts and the ability to design effective solutions.

In this study, we focused on forest roads on Mt. Graham in southeastern Arizona, USA, home of the critically endangered Mt. Graham red squirrel (Tamiasciurus hudsonicus grahamensis, hereafter, MGRS). The MGRS is a subspecies of the North American red squirrel (Tamiasciurus hudsonicus) that is endemic to, and isolated in, high elevation forests $(>2000 \mathrm{~m})$ at Mt. Graham, surrounded by desert and grassland. The red squirrel is a small (<300 g), diurnal tree squirrel with a wide ranging distribution in North America; MGRS represents the southernmost population [22,23]. Because of geographic isolation, declining and low population numbers ( 300 individuals) [24], and habitat destruction, the MGRS was listed as endangered in 1987 [25]. One primary threat to the MGRS is human disturbance from recreation, road traffic, and habitat modification associated with road improvement [21,26,27]. In the previous study, we found that the forest roads on Mt. Graham acted as barriers, and had long-term impacts on animal space use of Mt. Graham red squirrels. About one-third of the MGRS that were residents near roads were never observed to cross roads from 2008 to 2012 [21]. However, no crossing structure has been installed to enhance probability of road crossing on Mt. Graham.

A previous study found that the North American red squirrels used pipe culverts and box culverts to cross roads in a wildlife reserve in Quebec, Canada [28]. Therefore, the drainage culverts on Mt. Graham have the potential to mitigate the barrier effects of roads for the MGRS. Nevertheless, usage of pipe culverts by the MGRS, as well as other species of mammals on Mt. Graham, has not been assessed. Our study aimed to answer two research questions: (1) do Mt. Graham red squirrels and other mammals use small culverts to cross roads? (2) How do culverts attribute influence probability of use? To answer these questions, we used trail cameras to monitor 14 small culverts on Mt. Graham, and explored effects of culvert attributes on use of culverts. We predicted that MGRS and other mammals would use culverts to cross roads, and higher relative openness (width $\times$ height/length) of culverts would lead to higher probability of usage.

\section{Materials and Methods}

\subsection{Study Area}

Our study focused on two unpaved roads, $1.4 \mathrm{~km}$ of The Swift Trail (Arizona State Highway 366, 6- to 13-m wide, hereafter, SW) and $0.5 \mathrm{~km}$ of The Bible Camp Road (4to 9-m wide, hereafter, BC) located in the Pinaleño Mountains (hereafter, Mt. Graham), Graham County, Arizona, USA ( $\left(32^{\circ} 42^{\prime} 06^{\prime \prime} \mathrm{N}, 109^{\circ} 52^{\prime} 17^{\prime \prime} \mathrm{W}\right)$. Speed limit was $40 \mathrm{~km} / \mathrm{h}$. We used bi-directional traffic counters (TRAFx Vehicle Counter Model G3, TRAFx Research Ltd., Canmore, Alberta, Canada) to record traffic. Annual average daily traffic was 50 vehicles on the SW road and was 25 vehicles on the BC road. Roads were closed to the public from 15 November to 15 April annually. During road closure, average daily traffic volume decreased to $<10$ vehicles. Fourteen circular culverts with a diameter of $0.5 \mathrm{~m}$ were in place along the 2 roads ( 10 on SW, 4 on BC road, Figure 1), with a mean distance of $125.6 \mathrm{~m}( \pm 44.7 \mathrm{~m})$ between culverts. The forest was dominated by Douglas fir (Pseudotsuga menziesii), white fir (Abies concolor), and southwestern white pine (Pinus strobiformis), interspersed with corkbark fir (Abies lasiocarpa var. arizonica), Engelmann spruce (Picea engelmannii), aspen (Populus tremuloides), and ponderosa pine (Pinus ponderosa), at an elevation of 2870 to $3050 \mathrm{~m}$ [24]. 


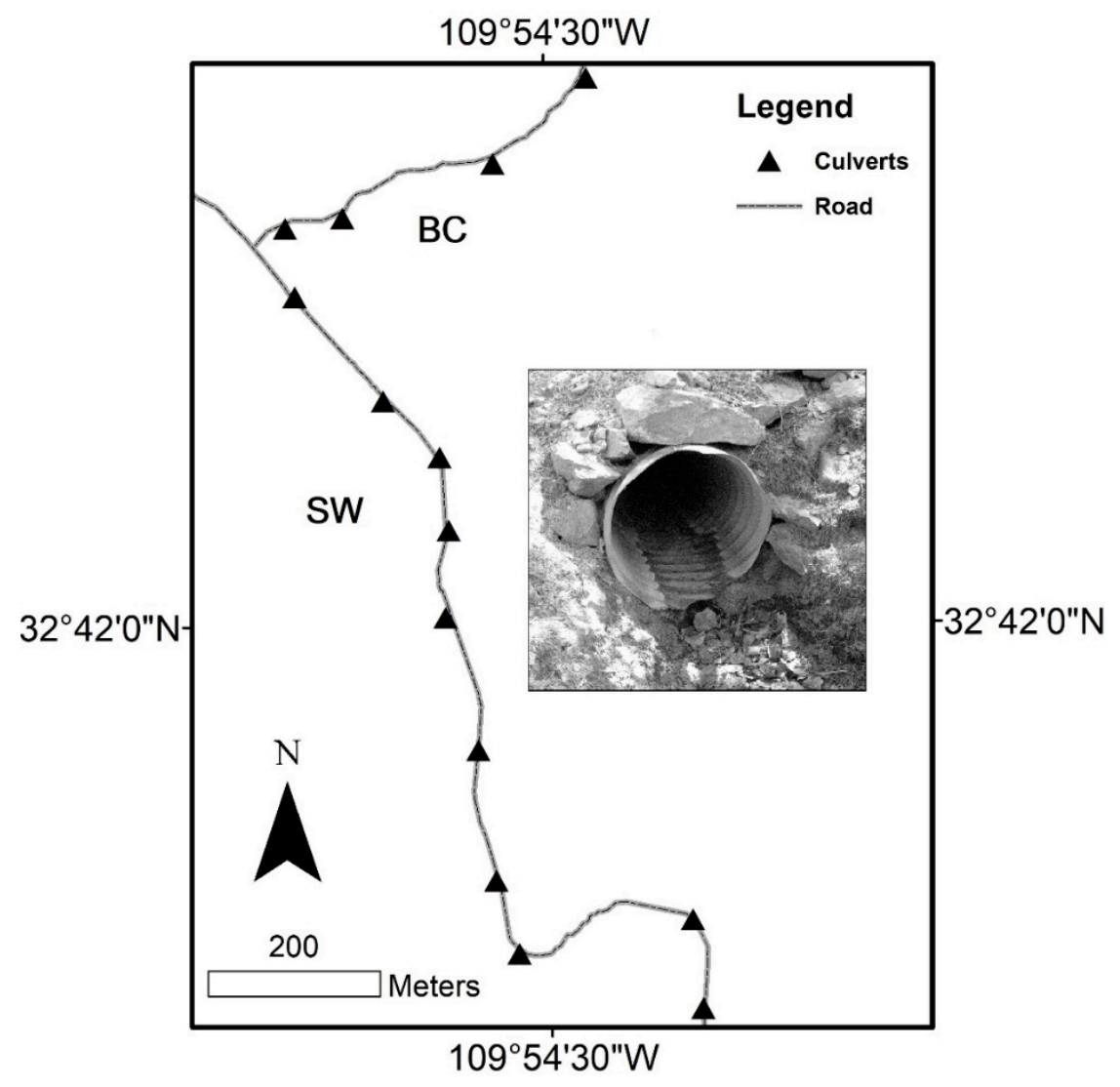

Figure 1. Location of culverts on The Swift Trail (Arizona State Highway 366, SW) and The Bible Camp Road (BC), Mt. Graham, AZ, USA.

\subsection{Use of Culverts by Mammals}

We used trail cameras (Bushnell Trophy Cam 119436c, TrailCamPro, Springfield, Missouri, USA) to monitor use of culverts by mammals at 14 culverts. For each culvert, we set two cameras to capture both culvert entrances ( $<2 \mathrm{~m}$ from the entrance) as well as the road surface. Cameras were installed at 0.5 to $2 \mathrm{~m}$ above the ground. We did not survey from December to February because culverts were not accessible due to accumulation of snow inside. After preliminary tests of camera settings, we set cameras at normal sensitivity to record one photo upon detection, with a 10-s delay between photographs to optimize performance, especially to decrease number of photos taken because of light. Field efforts were conducted under permits from the United States Department of Agriculture Forest Service, Arizona Game and Fish Department, United States Fish and Wildlife Service, and the University of Arizona's Institutional Animal Care and Use Committee (Protocol \#11-248).

We identified animals in photographs to species. For each species $>0.2 \mathrm{~kg}$, we recorded camera detections as the following events: approached, but did not cross road, completed road crossing on road surface, and completed road crossing through culverts. We eliminated species $<0.2 \mathrm{~kg}$ because of the inability of cameras with 10-s delay setting between photographs to detect road crossing by these species. We defined an approach as when an animal was detected by cameras. A completed road crossing on road surface was defined as an occasion where a species was detected on road surface at both sides of the road in $<2$ min span of time. We defined a completed road crossing through culverts when an animal was detected entering and exiting a culvert from different entrances $<2 \mathrm{~min}$. To avoid multiple records of any animals that stayed near the culvert's entrance, we only documented the same species once when captured $<1 \mathrm{~h}$ by the same camera. 


\subsection{Species Composition at Surrounding Forests}

Wildlife composition in the area may influence the use of culverts. For instance, lack of use of culverts by a given species may be due to the absence of the species in the surrounding area. Thus, in addition to monitor culverts, we also surveyed the composition of mammalian species of the surrounding forests. We used remote cameras to monitor 10 random locations selected in ArcGIS 9.0 and varied in distance from the road (38 to $130 \mathrm{~m}$ $(72.3 \pm 9.2 \mathrm{~m})$ ). For each random location, we placed three cameras facing the location, 5-10 $\mathrm{m}$ from the center point and 1-2 $\mathrm{m}$ above the ground, for a randomly assigned 6-day period, from May to September in 2011 and 2012. We set cameras at maximum sensitivity to record one photo upon detection, with a 3-s delay between photographs.

\subsection{Effects of Culvert Attributes on Use of Culverts to Cross Roads}

We characterized each culvert with the following variables: culvert length $(\mathrm{m})$ (representing openness), aperture (mean percentage through-culvert visibility taken from each entrance), presence or absence of water at the culvert, presence or absence of accumulated soil inside the culvert, aspect (degree from north), slope, and mean seasonal traffic volume. For detection records of completed road crossing (number of record $=65$ ), we used GLMM with a logit link function and binomial distribution to analyze probability of use culverts to cross roads with usage as a binary response variable (cross road through culverts, 1 ; cross road on road surface, 0 ). In the model, culvert attributes were set as fixed effects, and individual culvert was included as a random effect. We excluded record of deer, as the culverts were too small for deer to use. We did not assess influence of species because of the small dataset. We fitted GLMM with the lme4 (linear mixed-effects models using Eigen and S4: Bates et al., 2013) package in R (version 3.0.2 -"Frisbee Sailing", R Development Core Team 2008).

\section{Results}

\subsection{Use of Culverts by Mammals}

From 2011 to 2013, we obtained data from 1440 camera days. Each culvert was surveyed for at least 66 camera days (mean $103 \pm 27$ days) across different seasons. We detected 15 species of mammals at culverts, including seven species of carnivores: black bear (Ursus americanus; two detections), bobcat (Lynx rufus; 34 detections), gray fox (Urocyon cinereoargenteus; two detections), mountain lion (Puma concolor; one detection), raccoon (Procyon lotor; one detection), striped skunk (Mephitis mephitis; 126 detections), Western spotted skunk (Spilogale gracilis; two detections); three species of squirrels: Abert's squirrel (Sciurus aberti; 39 detections), Mt. Graham red squirrel (14 detections), rock squirrel (Spermophilus variegatus; 21 detections); 4 species of small mammals: cliff chipmunk (Tamias dorsalis; 169 detections), deer mice (Peromyscus maniculatus; 245 detections), long-tailed vole (Microtus longicaudus; 25 detections), Mexican woodrat (Neotoma mexicana; 63 detections); and white-tailed deer (Odocoileus virginianus; 82 detections).

We recorded 109 completed road crossings on road surface by mammals (Table S1). Road crossing by white-tailed deer (42 crossings), striped skunk (46 crossings), and bobcat (11 crossings) represented $90.9 \%$ of crossing events. We recorded 20 completed road crossing through culverts. Over half of uses of culverts $(70 \%)$ were by striped skunks (14 uses, Figures 2 and 3), followed by rock squirrels (20\%, four uses) and bobcats (10\%, 2 uses, Figures 2 and 3). The Mt. Graham red squirrel was the only species with $>5$ detections at culverts, but was not recorded in a completed road crossing nor a confirmed use of culvert.

\subsection{Species Composition at Surrounding Forest}

During the randomly assigned 6-day periods in 2011 and 2012 combined, we detected eight species of mammals at random locations: Abert's squirrel, black bear, cliff chipmunk, gray fox, Mt. Graham red squirrel, striped skunk, rock squirrel, and white-tailed deer. All species detected in the forest near roads were also detected at culverts. 


\subsection{Effects of Culvert Attributes on Use of Culverts to Cross Roads}

Comparing to cross roads on road surface, the probability of animals using culverts to cross roads increased when mean seasonal traffic volume increased. Culverts with higher usage were characterized by shorter culvert length and absence of accumulated soil inside the culverts (Table 1 ).

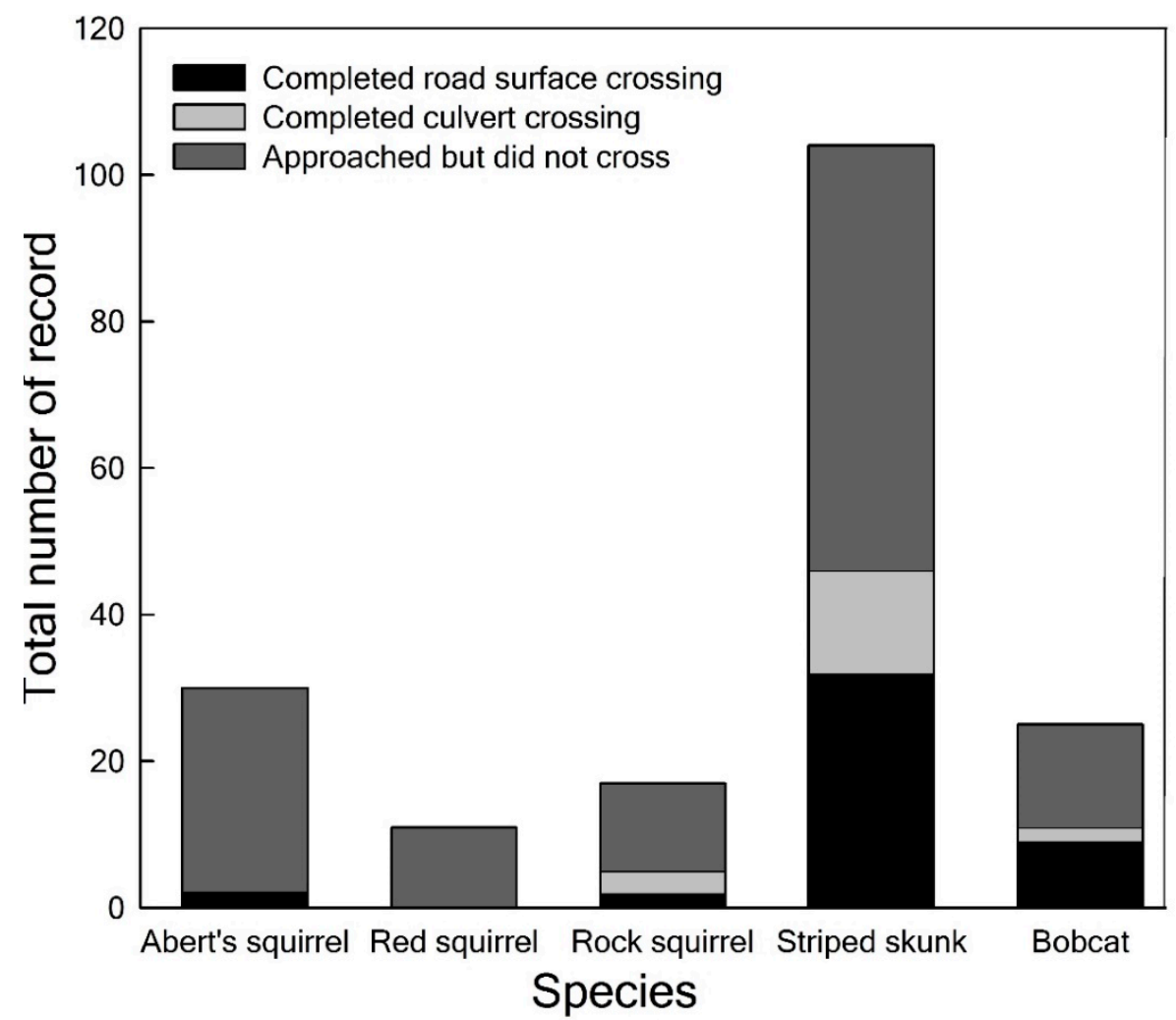

Figure 2. Frequency of road crossing through road surface, road crossing through culverts, and road approach by small to medium mammals, 2011-2013, Mt. Graham, AZ, USA.

Table 1. Coefficients of generalized linear mixed models for the probability of use of culverts to cross roads by mammals, Mt. Graham, AZ, USA.

\begin{tabular}{cccc}
\hline Variable & Odds Ratio * (Y/N) & SE & $p$ Value \\
\hline Culvert length $(\mathrm{m})$ & 0.03 & 4.74 & 0.03 \\
Aperture & 2.87 & 2.24 & 0.19 \\
Road traffic & 9.74 & 2.79 & 0.03 \\
Presence of accumulated soil & 0.02 & 6.50 & 0.03 \\
Degree from north & 0.08 & 2.00 & $<0.001$ \\
Slope & 0.30 & 2.45 & 0.18 \\
\hline
\end{tabular}

* The odds ratio represents the degree of change in odds ratio with 1-SD change in a continuous variable. 


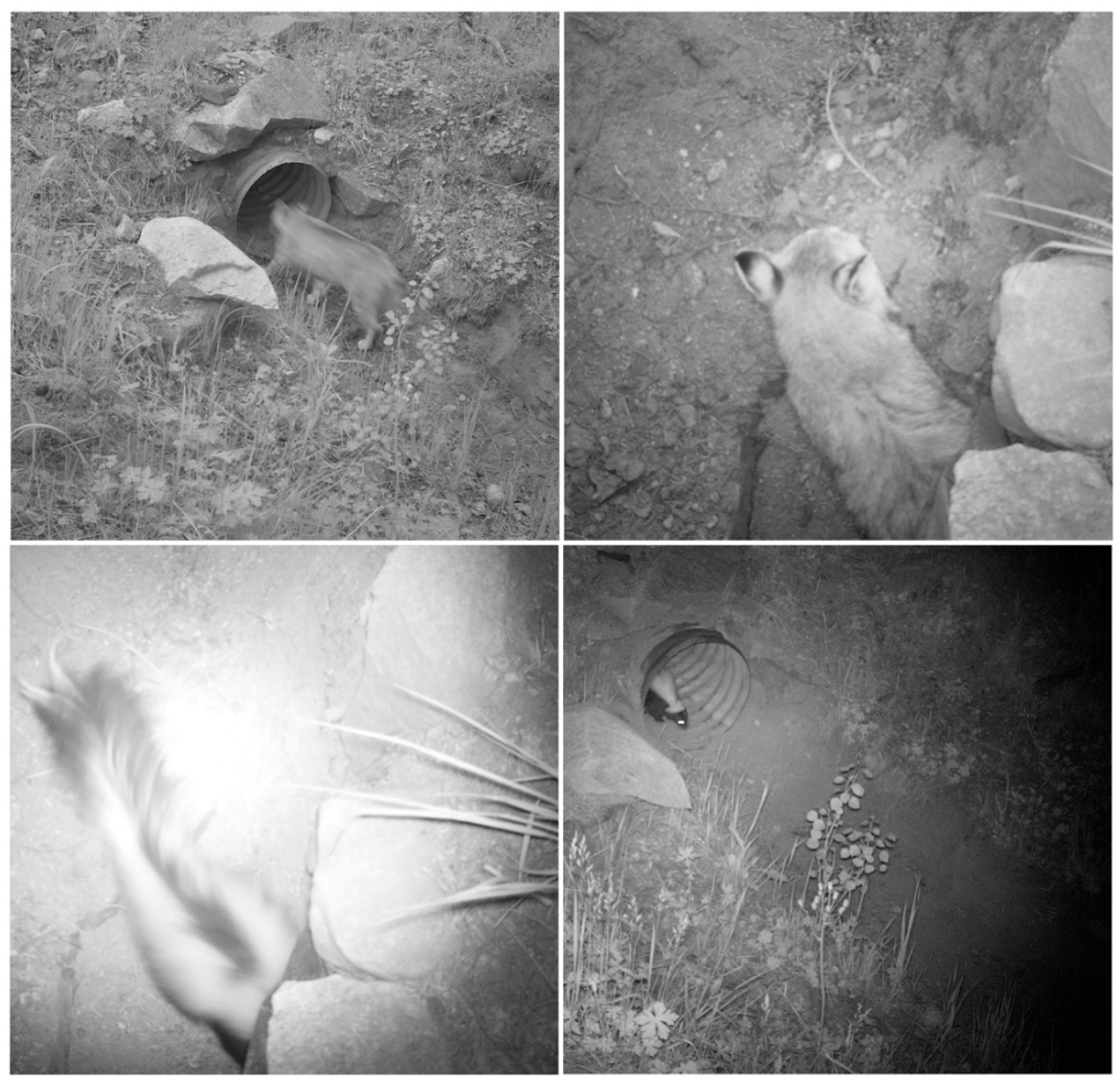

Figure 3. Pictures of uses of culverts to cross roads by bobcat (Lynx rufus) and striped skunk (Mephitis mephitis), Mt. Graham, AZ, USA.

\section{Discussion}

The overall use rate of culverts by mammals to cross roads in our study area was low, although we might underestimate the rate of road crossings due to inability of detecting crossing events by cameras with 10-s delay settings between photographs. The low use rate of culverts is not surprising, since the roads are relatively permeable due to low traffic volume ( $<100$ vehicles/day), unpaved road surface, and narrow road width. However, the rarity of road crossings and use of culverts by MGRS in the study area is particularly of concern. Although the North American red squirrels used large pipe culverts and box culverts to cross roads [28], our results show that small pipe culverts with a diameter of $50 \mathrm{~cm}$ did not assist road crossings for the MGRS. Many arboreal mammals, such as squirrel gliders (Petaurus norfolcensis) and ringtail possums (Hemibelideus lemuroides), do not use ground wildlife crossing structures [29-31]. Given that MGRS has already suffered from habitat loss and destruction associated with severe fire, insect damage, and development [26,32], effective mitigation of barrier effects of roads appears prudent. For other species of mammals, our study shows that small-dimension drainage systems can provide alternative pathways for road crossings. Mesocarnivores, such as bobcats and skunks, travel along unpaved, low traffic roads [8,33,34], and frequently use culverts to cross roads $[15,16,35]$. Slow moving and ground dwelling species (e.g., skunks) may benefit most from the existing culverts because skunks are found to be associated with roads and residential areas and are frequently killed by vehicles [36,37].

The results of our models assessing the influence of culvert attributes on probability of usage for road crossings were biased in species, as striped skunks represented $70 \%$ of usage of culverts. Nevertheless, we were able to identify attributes related to culvert 
structure and maintenance that may enhance animal movements. Openness was shown to be a positive predictor for use of culverts by small carnivores, such as the American marten (Martes American) [16]. Similarly, we also found that shorter culvert lengths (which means higher openness) had positive effects on probability of use. In addition to structural characteristics, the results show that animals were more likely to use culverts on roads with higher seasonal traffic volume. Animals use underpasses instead of overpasses or wildlife crosswalks during hours of peak traffic, possibly to avoid traffic disturbances, such as noise [38]. Along this line, culverts can serve as alternative routes to cross roads when traffic volume is high. However, one major cause that decreases culvert usage is inaccessibility resulting from accumulation of soil inside culverts, especially during the summer monsoon season. With increased traffic and animal activity in the summer, inaccessibility severely diminishes the functioning of small culverts as wildlife passages.

\section{Conclusions}

Movement of animals through landscapes to colonize fragmented habitat patches is critical to maintain connectivity, population persistence, and genetic variability of species [11]. Adapting existing drainages and culverts for wildlife use is a relatively easy and cost- effective way to provide wildlife passages. Our study shows that widespread, small-dimension drainage systems may provide alternative pathways for wildlife to cross roads. However, the potential of small culverts in assisting wildlife crossings can only be maximized when culverts are accessible year-round.

Supplementary Materials: The following are available online at https:/ / www.mdpi.com/article/10 .3390/su13137224/s1, Table S1: Data of recorded events at culverts, Mt. Graham, Arizona, USA.

Author Contributions: Conceptualization, H.-L.C. and J.L.K..; methodology, H.-L.C., E.E.P., and J.L.K.; formal analysis, H.-L.C.; investigation, H.-L.C. and E.E.P.; writing-original draft preparation, H.-L.C.; writing - review and editing, H.-L.C., E.E.P., and J.L.K.; supervision, J.L.K.; project administration, J.L.K.; funding acquisition, H.-L.C. and J.L.K. All authors have read and agreed to the published version of the manuscript.

Funding: We thank the USDA Forest Service Rocky Mountain Research Station, University of Arizona, T\&E, Inc. Grants for Conservation Biology Research, and the American Society of Mammalogists (Grants-in-Aid Program) for providing funding.

Institutional Review Board Statement: Field efforts were conducted under permits from the United States Department of Ag-riculture Forest Service, Arizona Game and Fish Department, United States Fish and Wildlife Service, and the University of Arizona's Institutional Animal Care and Use Committee (Protocol \#11-248).

Informed Consent Statement: Not applicable.

Data Availability Statement: The data presented in this study are available in Supplementary Material: Table S1.

Acknowledgments: We thank the University of Arizona Police Department in assisting in the search for missing research equipment. The anonymous reviewers who provided valuable comments on earlier versions of this manuscript are warmly acknowledged.

Conflicts of Interest: The authors declare no conflict of interest.

\section{References}

1. Czech, B.; Krausman, P.R. Distribution and causation of species endangerment in the United States. Science 1997, 277, 1116-1117. [CrossRef]

2. Forman, R.T.T.; Alexander, L.E. Roads and their major ecological effects. Annu. Rev. Ecol. Syst. 1998, 29, 207-231. [CrossRef]

3. Central Intelligence Agency. The World Factbook. Available online: https://www.cia.gov/library/publications/the-worldfactbook/ (accessed on 20 December 2014).

4. Trombulak, S.C.; Frissell, C.A. Review of ecological effects of roads on terrestrial and aquatic communities. Conserv. Biol. 2000, 14, 18-30. [CrossRef] 
5. Laurance, W.F.; Goosem, M.; Laurance, S.G.W. Impacts of roads and linear clearings on tropical forests. Trends Ecol. Evol. 2009, 24, 659-669. [CrossRef]

6. Clark, R.W.; Brown, W.S.; Stechert, R.; Zamudio, K.R. Roads, interrupted dispersal, and genetic diversity in timber rattlesnakes. Conserv. Biol. 2010, 24, 1059-1069. [CrossRef]

7. Goosem, M. Effects of tropical rainforest roads on small mammals: Fragmentation, edge effects and traffic disturbance. Wildl. Res. 2002, 29, 277-289. [CrossRef]

8. Coffin, A.W. From roadkill to road ecology: A review of the ecological effects of roads. J. Transp. Geogr. 2007, 15, 396-406. [CrossRef]

9. Fahrig, L.; Rytwinski, T. Effects of roads on animal abundance: An empirical review and synthesis. Ecol. Soc. 2009, 14, 21. [CrossRef]

10. Hanski, I.; Gilpin, M. Metapopulation dynamics: Brief history and conceptual domain. Biol. J. Linn. Soc. 1991, 42, 3-16. [CrossRef]

11. Frankham, R. Relationship of genetic variation to population size in wildlife. Conserv. Biol. 1996, 10, 1500-1508. [CrossRef]

12. Holderegger, R.; Di Giulio, M. The genetic effects of roads: A review of empirical evidence. Basic Appl. Ecol. 2010, 11, 522-531. [CrossRef]

13. Ruediger, W.; Wall, K.; Wall, R. Effects of highways on elk habitat in the Western United States and proposed mitigation approaches. In Proceedings of the 2005 International Conference on Ecology and Transportation, San Diego, CA, USA, 29 August-2 September 2005; North Carolina State University: Raleigh, NC, USA, 2005; pp. 269-278.

14. Taylor, B.D.; Goldingay, R.L. Roads and wildlife: Impacts, mitigation and implications for wildlife management in Australia. Wildl. Res. 2010, 37, 320-331. [CrossRef]

15. Yanes, M.; Velasco, J.M.; Suarez, F. Permeability of roads and railways to vertebrates: The importance of culverts. Biol. Conserv. 1995, 71, 217-222. [CrossRef]

16. Clevenger, A.P.; Chruszcz, B.; Gunson, K. Drainage culverts as habitat linkages and factors affecting passage by mammals. J. Appl. Ecol. 2001, 38, 1340-1349. [CrossRef]

17. Forman, R.T.T.; Sperling, D.; Bissonette, J.A.; Clevenger, A.P.; Cutshall, C.D.; Dale, V.H.; Fahrig, L.; France, R.L.; Goldman, C.R.; Heanue, K.; et al. Road Ecology: Science and Solutions, 2nd ed.; Island Press: Washington, DC, USA, 2003.

18. Ascensão, F.; Mira, A. Factors affecting culvert use by vertebrates along two stretches of road in southern Portugal. Ecol. Res. 2007, 22, 57-66. [CrossRef]

19. Coghlan, G.; Sowa, R. National Forest Road System and Use; Draft Report, 1-30-98, Engineering Staff; USDA Forest Service: Washington, DC, USA, 1998.

20. Iglesias, C.; Mata, C.; Malo, J.E. The influence of traffic noise on vertebrate road crossing through underpasses. Ambio 2012, 41, 193-201. [CrossRef]

21. Chen, H.L.; Koprowski, J.L. Barrier effects of roads on an endangered forest obligate: Influences of traffic, road edges, and gaps. Biol. Conserv. 2016, 199, 33-40. [CrossRef]

22. Brown, D.E. Arizona's Tree Squirrels; Arizona Game and Fish Department: Phoenix, AZ, USA, 1984.

23. Steele, M.A. Tamiasciurus hudsonicus. Mamm. Species 1998, 586, 1-9. [CrossRef]

24. Sanderson, H.R.; Koprowski, J.L. The Last Refuge of the Mt. Graham Red Squirrel; University of Arizona Press: Tucson, AZ, USA, 2009.

25. U.S. Fish and Wildlife Service. Endangered and threatened wildlife and plants; determination of endangered status for the Mount Graham red squirrel. Fed. Regist. 1987, 52, 20994-20999.

26. Buenau, K.E.; Gerber, L.R. Developing recovery and monitoring strategies for the endemic Mount Graham red squirrels (Tamiasciurus hudsonicus grahamensis) in Arizona. Anim. Conserv. 2004, 7, 17-22. [CrossRef]

27. Chen, H.L.; Koprowski, J.L. Animal occurrence and space use change in the landscape of anthropogenic noise. Biol. Conserv. 2015, 192, 315-322. [CrossRef]

28. Martinig, A.R.; Bélanger-Smith, K. Factors influencing the discovery and use of wildlife passages for small fauna. J. Appl. Ecol. 2016, 53, 825-836. [CrossRef]

29. Taylor, B.D.; Goldingay, R.L. Cutting the carnage: Wildlife usage of road culverts in north-eastern New South Wales. Wildl. Res. 2003, 30, 529. [CrossRef]

30. Wilson, R.F.; Marsh, H.; Winter, J. Importance of canopy connectivity for home range and movements of the rainforest arboreal ringtail possum (Hemibelideus lemuroides). Wildl. Res. 2007, 34, 177-184. [CrossRef]

31. Van derRee, R.; Cesarini, S.; Sunnucks, P.; Moore, J.L.; Taylor, A. Large gaps in canopy reduce road crossing by a gliding mammal. Ecol. Soc. 2010, 15, 35. [CrossRef]

32. Zugmeyer, C.A.; Koprowski, J.L. Severely insect-damaged forest: A temporary trap for red squirrels? For. Ecol. Manag. 2009, 257, 464-470. [CrossRef]

33. Lovallo, M.J.; Anderson, E.M. Bobcat movements and home ranges relative to roads in Wisconsin. Wildl. Soc. Bull. 1996, 24, 71-76.

34. Riley, S.P.D. Spatial ecology of bobcats and gray foxes in urban and rural zones of a national park. J. Wildl. Manag. 2006, 70, 1425-1435. [CrossRef]

35. Cain, A.T.; Tuovila, V.R.; Hewitt, D.G.; Tewes, M.E. Effects of a highway and mitigation projects on bobcats in Southern Texas. Biol. Conserv. 2003, 114, 189-197. [CrossRef] 
36. Barthelmess, E.L.; Brooks, M.S. The influence of body-size and diet on road-kill trends in mammals. Biodivers. Conserv. 2010, 19, 1611-1629. [CrossRef]

37. Klinkowski-Clark, C.; Kutilek, M.J.; Matson, J.O.; Messina, P.; Earley, K.; Bros-Seeman, S.M. Estimating relative distribution of raccoons, opossums, skunks, and foxes using animal control data. Hum. Wildl. Interations 2010, 4, 32-46.

38. Gagnon, J.W.; Theimer, T.C.; Dodd, N.L.; Boe, S.; Schweinsburg, R.E. Traffic volume alters elk distribution and highway crossings in Arizona. J. Wildl. Manag. 2007, 71, 2318-2323. [CrossRef] 